\title{
Stress Distribution in a Coal Seam before and after Bump Initiation
}

\author{
J. Vacek
}

This paper deals with to the behaviour of open rock that occurs, for example, during longwall mining in coal mines, in deep tunnel, or shaft excavation.

Longwall instability leads to extrusion of rock mass into an open space. This effect is mostly referred to as a bump, or a rock burst. For bumps to occur, the rock has to possess certain particular rock burst properties leading to accumulation of energy and the potential to release this energy. Such materials may be brittle, or the bumps may arise at the interfacial zones of two parts of the rock, that have principally different material properties.

The solution is based on experimental and mathematical modelling. These two methods have to allow the problem to be studied on the basis of three presumptions:

- the solution must be time dependent

- the solution must allow the creation of crack in the rock mass

- the solution must allow an extrusion of rock into an open space (bump effect)

Keywords: rock bursts, bumps, mining, rock mechanics, mathematics and physical modelling.

\section{Introduction}

In July 1995 our institute was awarded funding for a project on "Model experiments on the pressure distribution in a coal seam, or in a wide coal pillar, before and after bump initiation" in the framework of the Volkswagen Foundation. The project was led by the Technische Universität München, represented by Prof. Dr. Dr.h.c. Horst Lippmann, and the coapplicant was the of the Czech Technical University in Prague, Klokner Institute represented by Jaroslav Vacek.

TUM supervised the project and supplied technicians to operate the $10 \mathrm{MN}$ testing machine and to help with assembling and disassembling the device. This took a total of 30 days, in which the testing machine was exclusively reserved for the Volkswagen Project.

All other research work was carried out in Prague. Research work is now continuing in the framework of a Czech grant.

\section{Testing devices}

\subsection{Loading cell}

Fig. 1 shows the loading cell. It consists of the lower steel tank, which is designed for the horizontal forces caused by the vertical load in araldite specimens. The loading cell is equipped with plexiglass on its sides which allows the samples to be observed during the tests. The tank is shown on Photo 2. This loading cell models (simulates) the rock mass in the vicinity of the seam. In the loading cell we placed two araldite specimens (with dimensions of 160/400/40 mm), which model a real seam. The gap between them corresponds to the width of a working gallery in a mine. We observed the mechanism and the history of coal bumps. The araldite specimen was covered with a soft dural sheet, and a force meters were placed on it in the following manner: 5 comparatively thick force meters were placed near its outer edge and another 15 thinner force meters were placed next to them, (see Fig. 1 and

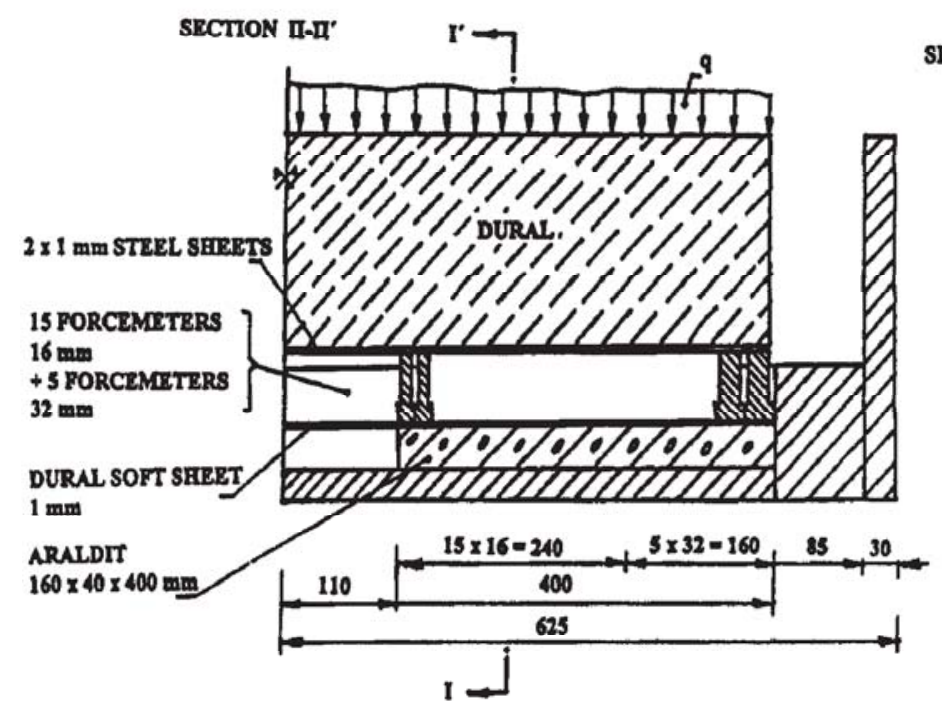

SECTION IN'

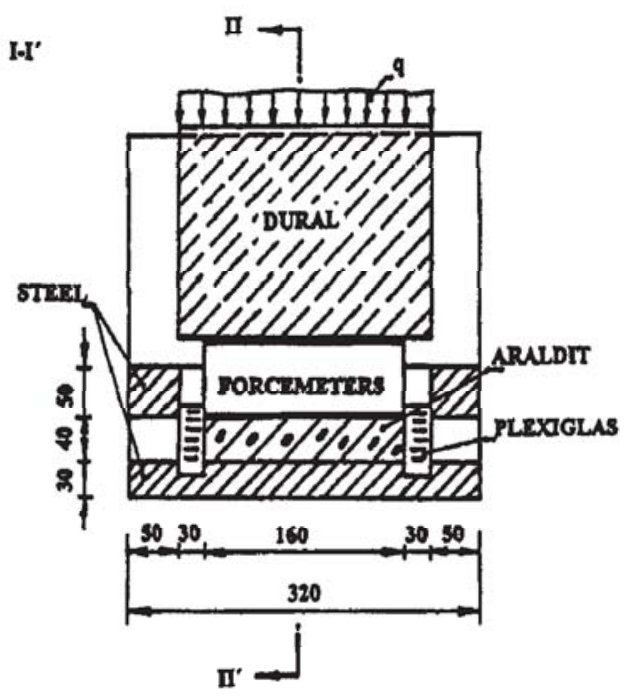

Fig. 1: Scheme of loading cell 


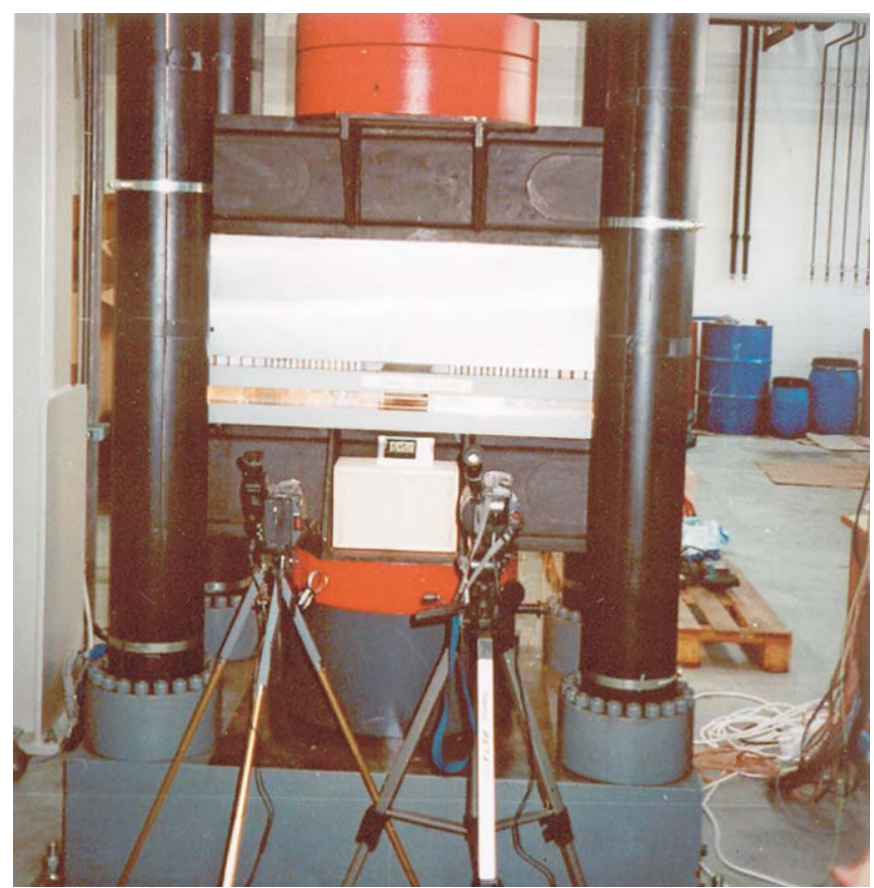

Photo 1: Testing device. Two camcorders recorded the test.

Photo 2). In order to embed the force meters properly and to prevent them from tilting, another double steel sheet, $1 \mathrm{~mm}$ thick, was placed over the force meters. A $300 \mathrm{~mm}$ high block of duraluminium was placed over this sheet. This block simulates the handing wall and facilitates stress distribution similar to that in reality (see Photo 1).

\subsection{Force meters}

Photo 2 shows the force meters. The force meters are $160 \mathrm{~mm}$ in length, $68 \mathrm{~mm}$ in height, and 16 or $32 \mathrm{~mm}$ in width. There are 4 strain gauges on each force meter -2 on one side $30 \mathrm{~mm}$ from the edge of the force meter and 2 on the other side $60 \mathrm{~mm}$ from the edge of the force meter. These allow us to measure the deformation along its full length. The strain gauges are connected in series in order to be able to gauge each force meter separately and at the same time to increase the gauging sensitivity. The force meters indicated by numbers $1,2, \ldots 30$ (width $16 \mathrm{~mm}$ ), 31, 32, .. 40 (width $32 \mathrm{~mm}$ ) were calibrated within the expected range of forces, i.e., 0 to $250(500) \mathrm{kN}$.

\subsection{Experimental verification of the measuring system}

The stability of the measuring system in the unloaded state was verified for approximately 26 hours. The values of the readings in the unloaded force meters were measured at 5 minute intervals.

The random error of the measuring system is characterised by the floating deviation (derived from 480 values); it approximately $0.50 \mathrm{kN}$. The errors of the gauging electronic system are only small, with a value less than approximately 0.3 $\%$ of the maximum gauged range.

\section{Survey of recorded bumps}

Table 1 surveys the forces that acted during the recorded bumps. The evaluation of their intensity is subjective.

We can conclude that

- the first bumps were recorded at forces 1100-1700 kN. The lack of bumps for VW 01-03 is probably because we failed to recognise them until we had gained some experience. The best way to recognize a bump is by noticing the drop in force at the press or the changes in the stress registered by the force meters.

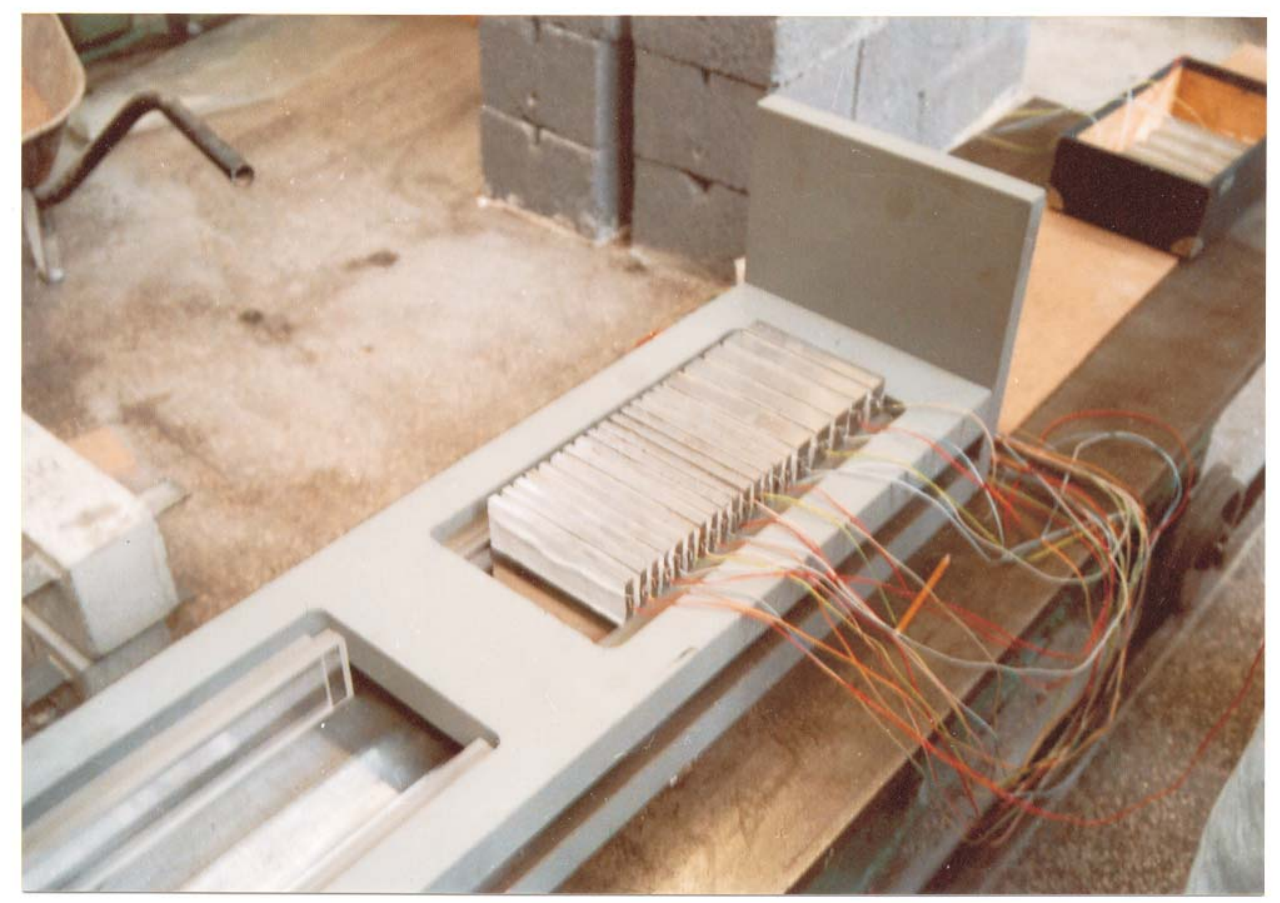

Photo 2: Loading cell. Right with sample and force meters. 
Table 1: Total number of determined bumps

\begin{tabular}{|c|c|c|c|c|c|c|c|c|c|c|c|c|c|}
\hline ModelVW & 01 & 02 & 03 & 04 & 06 & 07 & 11 & 12 & 13 & 14 & 20 & 21 & 22 \\
\hline Test location & ZUS & $\mathrm{KI}$ & TUM & TUM & TUM & TUM & TUM & TUM & TUM & TUM & TUM & TUM & TUM \\
\hline \multirow[t]{7}{*}{$\begin{array}{l}\text { The total force } \\
\text { (MN) acting } \\
\text { during the bump } \\
\text { and eveluation } \\
\text { of its intensity }\end{array}$} & & & & $\begin{array}{c}1.500 \\
W \\
1700 \\
W \\
\end{array}$ & & & $\begin{array}{c}1.150 \\
W\end{array}$ & $\begin{array}{c}1.400 \\
W\end{array}$ & & $\begin{array}{c}1.100 \\
W\end{array}$ & $\begin{array}{c}1.600 \\
W \\
1.900 \\
W \\
\end{array}$ & & $\begin{array}{c}1.150 \\
W\end{array}$ \\
\hline & & & $\begin{array}{c}2.900 \\
W\end{array}$ & $\begin{array}{c}2.600 \\
W\end{array}$ & $\begin{array}{c}2.723 \\
\mathrm{M}\end{array}$ & $\begin{array}{l}2.200 \\
\mathrm{~W} \\
2.760 \\
\mathrm{~W} \\
\end{array}$ & $\begin{array}{l}2.150 \\
\mathrm{~W} \\
2550 \\
\mathrm{~W} \\
\end{array}$ & $\begin{array}{c}2.700 \\
\mathrm{~S}\end{array}$ & $\begin{array}{c}2.222 \\
W\end{array}$ & & $\begin{array}{c}2.900 \\
\mathrm{~S}\end{array}$ & $\begin{array}{c}2.500 \\
W\end{array}$ & \\
\hline & $\begin{array}{c}3.500 \\
\mathrm{~S}\end{array}$ & & & & $\begin{array}{c}3.280 \\
\mathrm{~S}\end{array}$ & $\begin{array}{c}3.189 \\
\mathrm{~S}\end{array}$ & $\begin{array}{c}3.367 \\
\mathrm{~S}\end{array}$ & $\begin{array}{c}3.100 \\
W\end{array}$ & $\begin{array}{c}3.080 \\
\mathrm{M} \\
3.500 \\
\mathrm{M} \\
\end{array}$ & $\begin{array}{c}3.400 \\
\text { M-S }\end{array}$ & & & $\begin{array}{c}3.169 \\
\mathrm{M}\end{array}$ \\
\hline & & $\begin{array}{c}3.700 \\
\mathrm{~W} \\
4.400 \\
\mathrm{~S} \\
\end{array}$ & $\begin{array}{l}3.700 \\
\mathrm{~W} \\
4.260 \\
\mathrm{~S} \\
\end{array}$ & & $\begin{array}{c}4.080 \\
\text { M-S }\end{array}$ & $\begin{array}{c}4.147 \\
\text { S }\end{array}$ & & $\begin{array}{c}4.060 \\
\mathrm{M}\end{array}$ & $\begin{array}{c}4.300 \\
W\end{array}$ & $\begin{array}{c}4.270 \\
\text { M-S }\end{array}$ & $\begin{array}{l}4.170 \\
\text { VS }\end{array}$ & $\begin{array}{c}3.970 \\
\mathrm{M}\end{array}$ & $\begin{array}{c}3.790 \\
\mathrm{~W} \\
4.200 \\
\mathrm{M}\end{array}$ \\
\hline & $\begin{array}{c}4.880 \\
\mathrm{~S}\end{array}$ & & & $\begin{array}{c}4.900 \\
\mathrm{~S}\end{array}$ & $\begin{array}{c}4.980 \\
\mathrm{~S}\end{array}$ & $\begin{array}{c}5.365 \\
\text { S }\end{array}$ & $\begin{array}{c}4.520 \\
\mathrm{M}\end{array}$ & $\begin{array}{c}5.000 \\
\mathrm{~S}\end{array}$ & $\begin{array}{c}4.940 \\
\mathrm{~S}\end{array}$ & $\begin{array}{c}4.960 \\
\text { M-S }\end{array}$ & $\begin{array}{l}5.170 \\
\mathrm{~W} \\
5.300 \\
\text { VS } \\
\end{array}$ & $\begin{array}{c}4.640 \\
\text { M-S } \\
5.500 \\
\text { W } \\
\end{array}$ & $\begin{array}{c}4.900 \\
\mathrm{~W} \\
5.400 \\
\mathrm{M} \\
\end{array}$ \\
\hline & & & & & $\begin{array}{c}5.540 \\
\text { VS }\end{array}$ & $\begin{array}{c}5.592 \\
\mathrm{~S}\end{array}$ & $\begin{array}{c}5.540 \\
\mathrm{~S}\end{array}$ & & $\begin{array}{c}5.670 \\
\text { S }\end{array}$ & $\begin{array}{c}5.480 \\
\mathrm{~S}\end{array}$ & & $\begin{array}{c}5.550 \\
\text { W }\end{array}$ & $\begin{array}{c}5.570 \\
\mathrm{~W} \\
5.760 \\
\mathrm{M}-\mathrm{S}\end{array}$ \\
\hline & $\begin{array}{c}6.000 \\
\mathrm{~S}\end{array}$ & & $\begin{array}{c}6.200 \\
\text { VS }\end{array}$ & $\begin{array}{c}6.470 \\
\text { VS }\end{array}$ & & & & $\begin{array}{c}6.000 \\
\mathrm{~S}\end{array}$ & & $\begin{array}{c}6.445 \\
\text { VS }\end{array}$ & $\begin{array}{c}6.000 \\
\text { VS }\end{array}$ & $\begin{array}{l}6.280 \\
\mathrm{M} \\
6.820 \\
\mathrm{~S}\end{array}$ & $\begin{array}{c}6.320 \\
\mathrm{~S}\end{array}$ \\
\hline
\end{tabular}

\section{Results of the tests}

These results are presented in the form of $p_{\mathrm{i}} / q$. An example is given in Fig. 2. Here $p_{\mathrm{i}}$ is the stress registered by the $\mathrm{i}$-th force meter and $q$ is the average stress inside the loading cell. We can observe the following kinds of dependence:

- For bumps which occurred when the load was low (1-1.5 $\mathrm{MN}$ ), when there were not too many cracks and the araldite was brittle, the maximum $p / q$ ratio was greater then 4 .
- The bumps that occur at higher loads exhibit a lower ratio; for $3 \mathrm{MN}$ the maxima are only three times higher and over $5 \mathrm{MN}$ the araldite becomes plastic and the values of $p_{\mathrm{i}}$ are only slightly higher than twice that of $q$. This is despite the fact that the empty space has increased by $30-50 \mathrm{~mm}$ on each side.

For six groups of stronger bumps, which occur for similar loads from 2.582 MN onward (where the bumps are listed

VW 03 - 4250/4505 kN

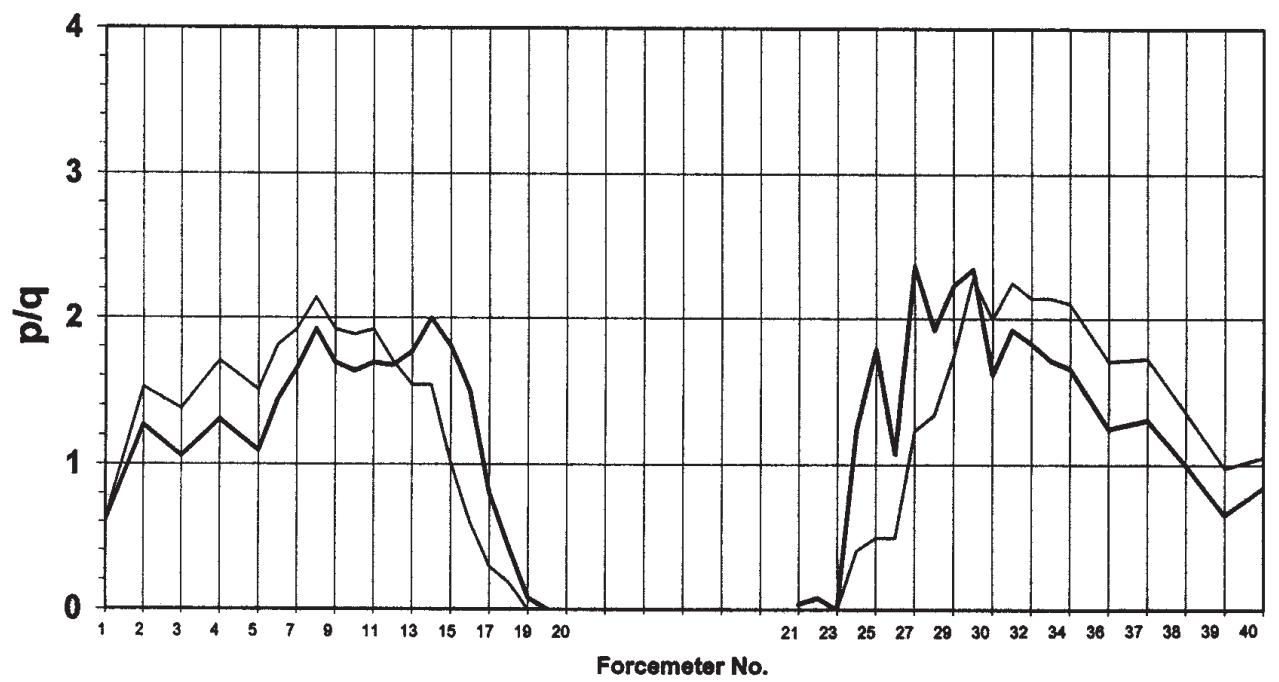

Fig. 2: Stress distribution of coal seam loading before (thick line) and after bump VW 03 


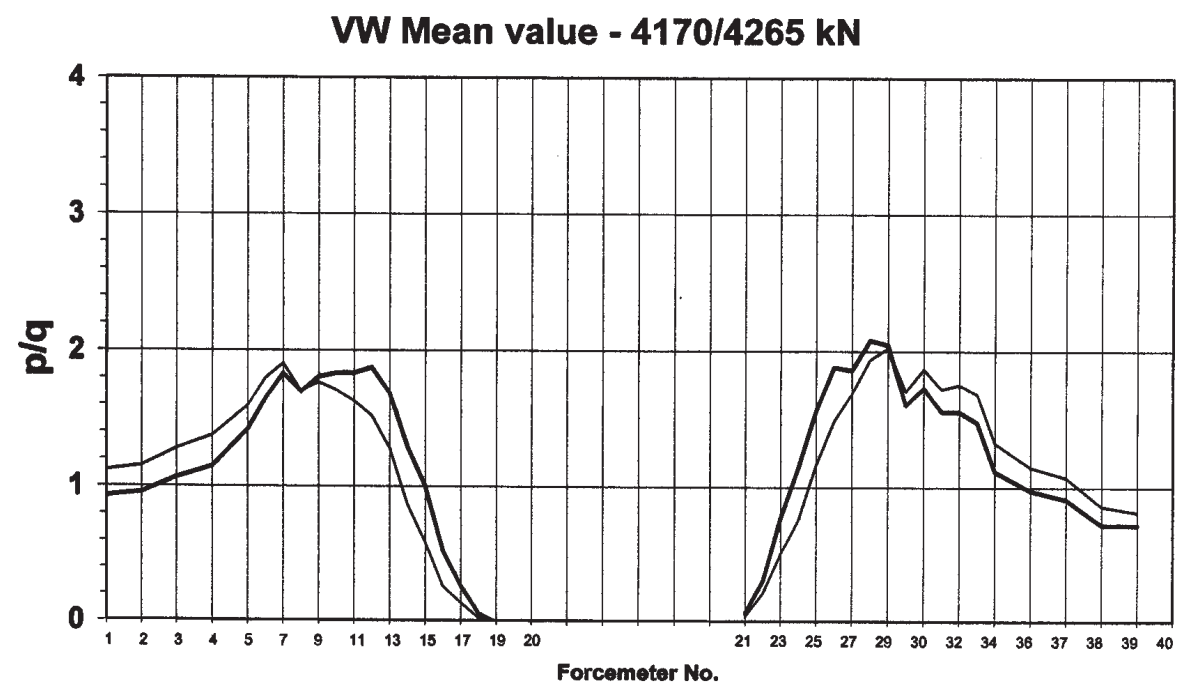

Fig. 3: Mean stress distribution of coal seam loading before (thick line) and after a bump. The force is 4170-4265, covered bump of models VW 03, 06, 07, 11, 12, 13, 14, 20, 21, 22.

\section{VW 21}

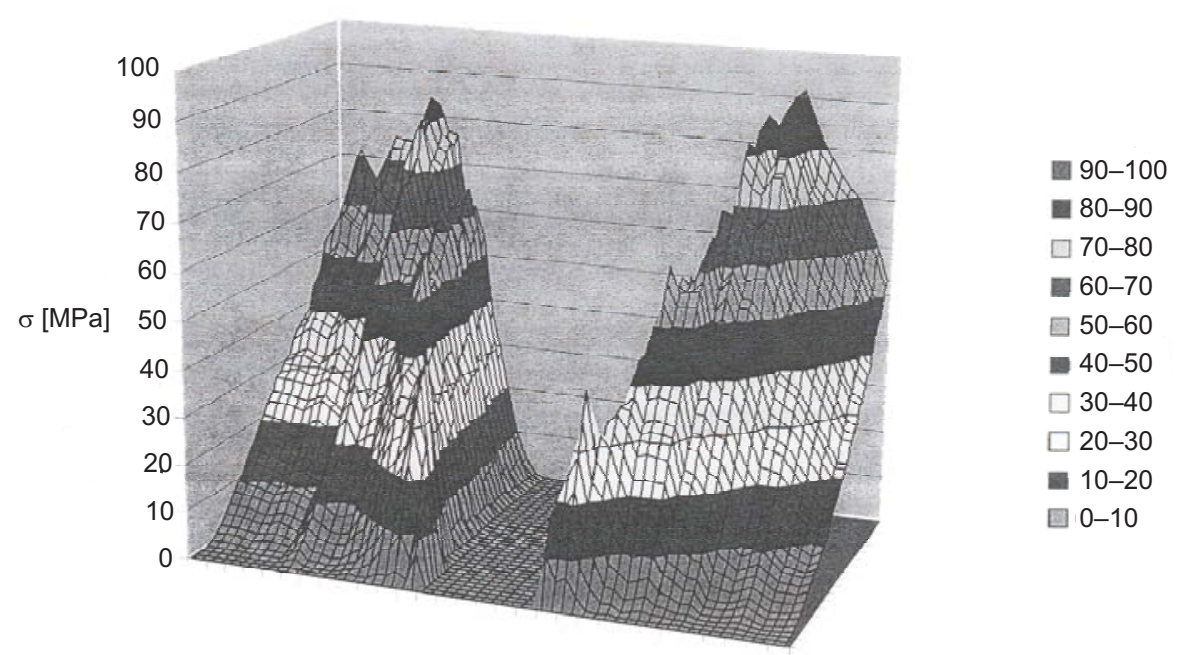

Fig. 4: Loading of the coal seam during test VW 21 in axonometry

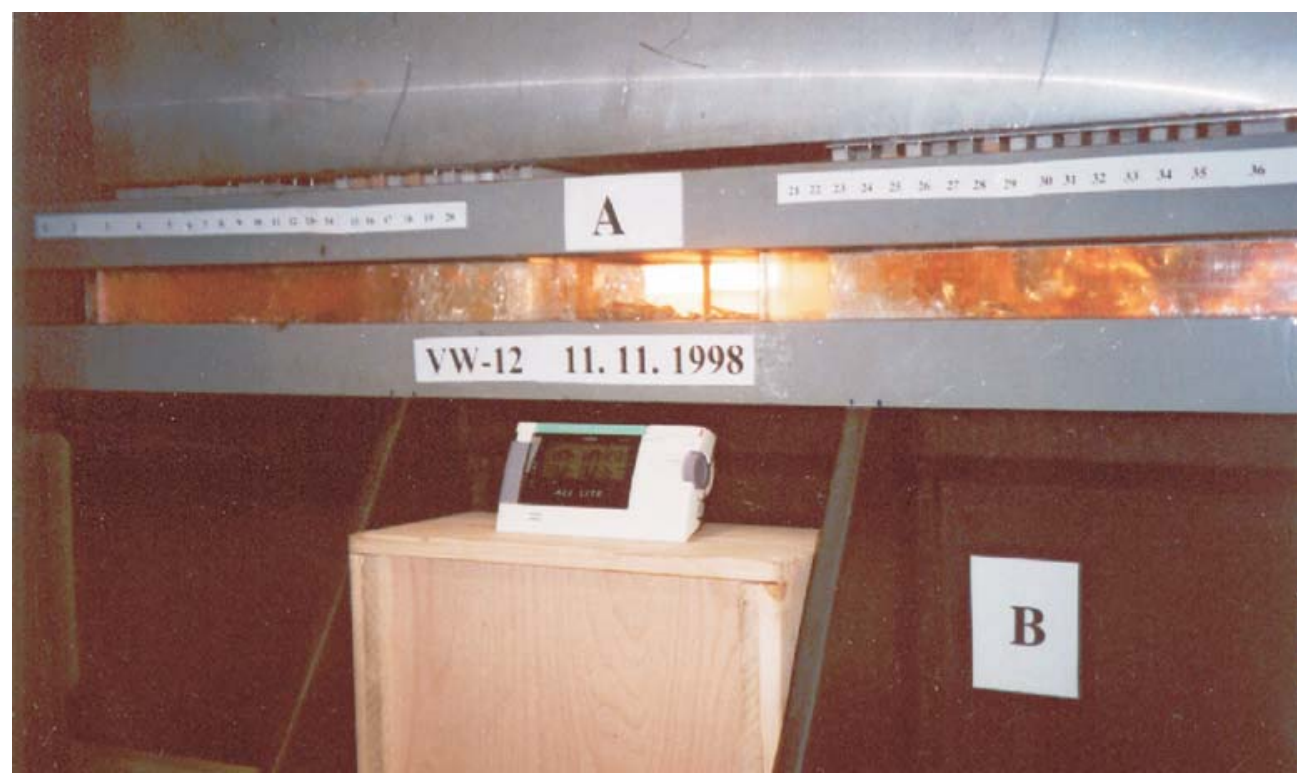

Photo 3: Detail of araldite samples at force $60 \mathrm{kN}$ 


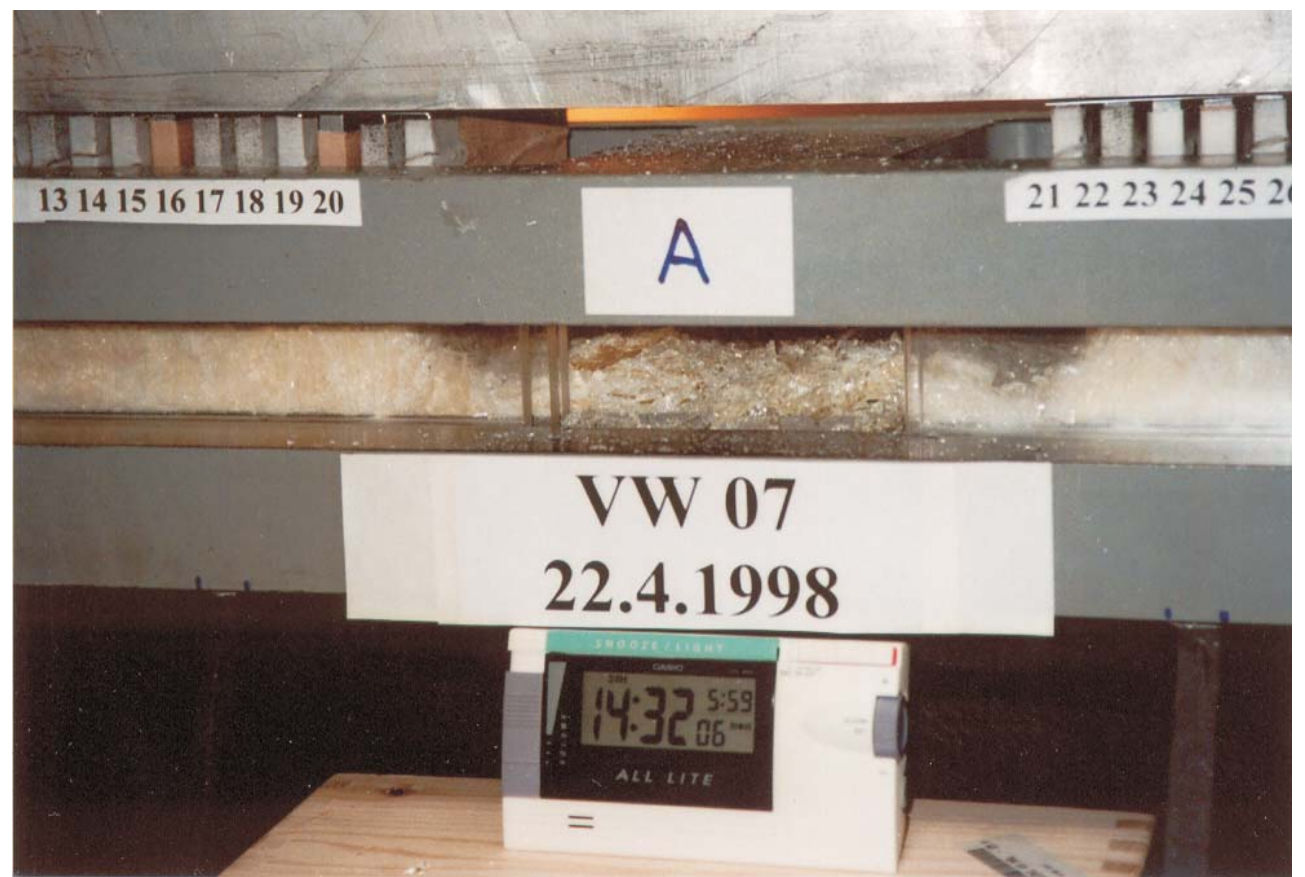

Photo 4: Detail of araldite samples at force 6.5 MN. At the centre extruded material can be seen.

together with average values and corresponding model numbers), we calculated the average values of $p_{\mathrm{i}} / q$. Fig. 3 provides an example.

- The maximum $p_{\mathrm{i}}$ equals approximately $2 q(1.8-2.2)$, which is the case for all loads on a loading cell bigger than $3 \mathrm{MN}$.

- The maximum for 3.2 MN occurs at the fifth force meter from the gap in the middle $(80 \mathrm{~mm})$, for $5.4 \mathrm{MN}$ at the $8^{\text {th }}$ to $12^{\text {th }}$ force meter $(130-190 \mathrm{~mm})$ and for a load of $6.4 \mathrm{MN}$ at the $12^{\text {th }}$ force meter, i.e., $190 \mathrm{~mm}$ from the original edge of the gap in the middle.

\section{Mathematical model}

$P F C^{2 D}$ (Particle Flow Code in Two Dimensions) developed by Itasca, USA was used for the numerical modelling part of the project. A physical problem concerning the movement and interaction of circular particles may be modelled directly by $\mathrm{PFC}^{2 \mathrm{D}}$. $\mathrm{PFC}^{2 \mathrm{D}}$ models the movement and interaction of circular particles by the distinct element method (DEM), as described by Cundall and Strack (1979).

Particles of arbitrary shape can be created by bonding two or more particles together: these groups of particles act as autonomous objects, provided that their bond strength is high. As a limiting case, each particle may be bonded to its neighbour: the resulting assembly can be regarded as a "solid" that has elastic properties and is capable of "fracturing" when the bonds break in a progressive manner. $P F C^{2 D}$ contains extensive logic to facilitate the modelling of solids as close-packed assemblies of bonded particles; the solid may be homogeneous, or it may be divided into a number of discrete regions of blocks.

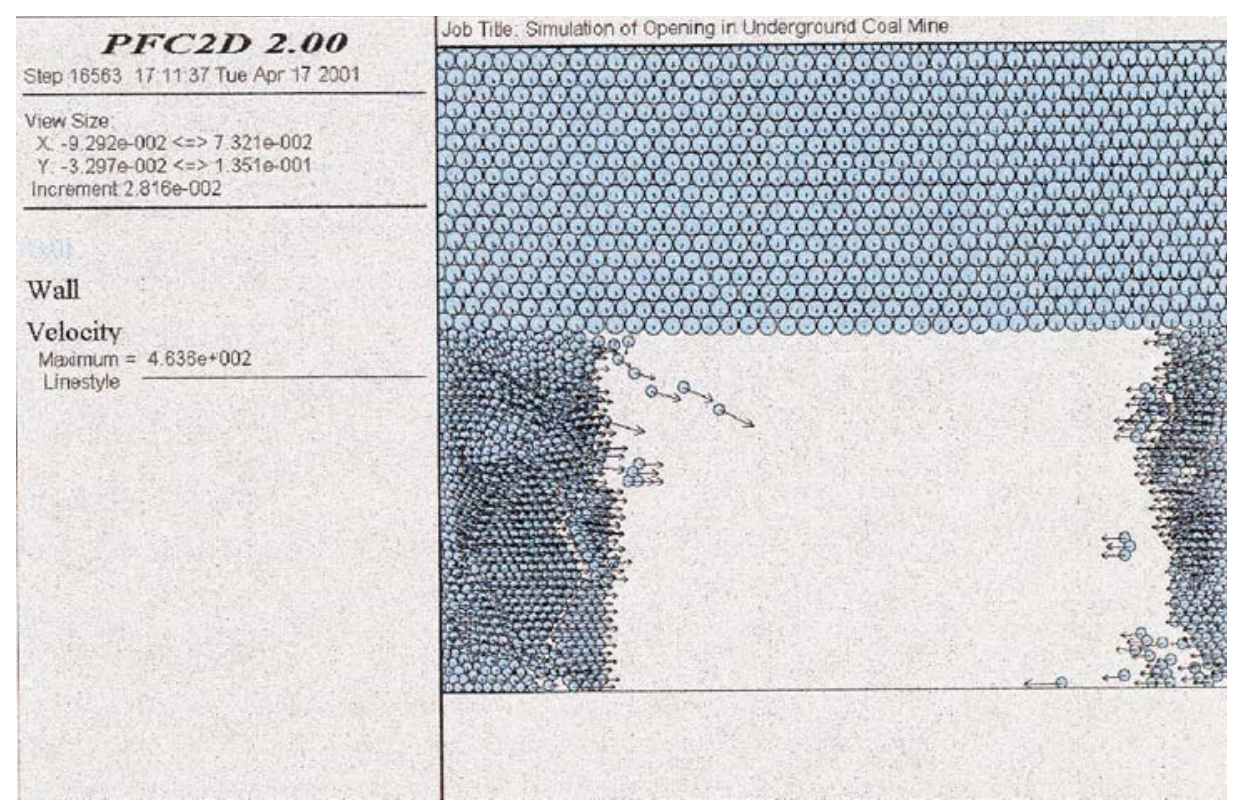

Fig. 5: Detail of the model immediately after a bump (with ball velocities). The first cracks are cleary visible. 


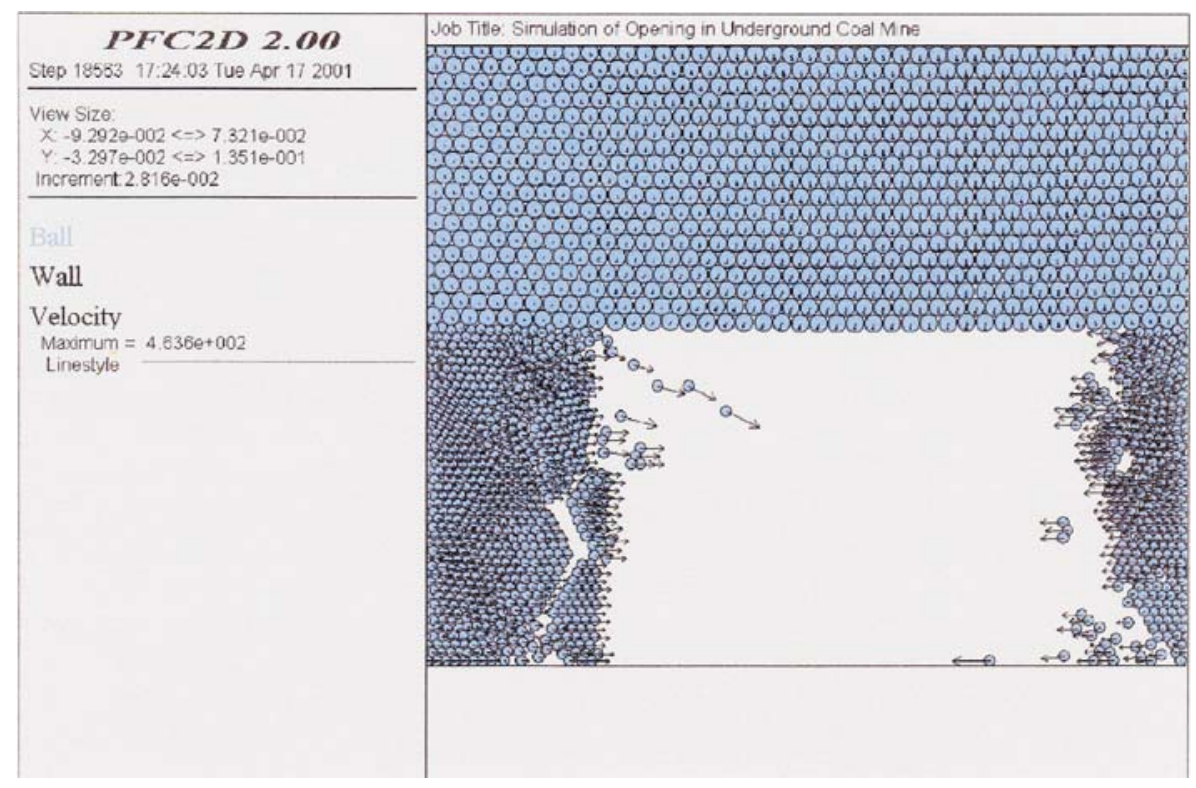

Fig. 6: Detail of the model some time after a bump (with ball velocities)

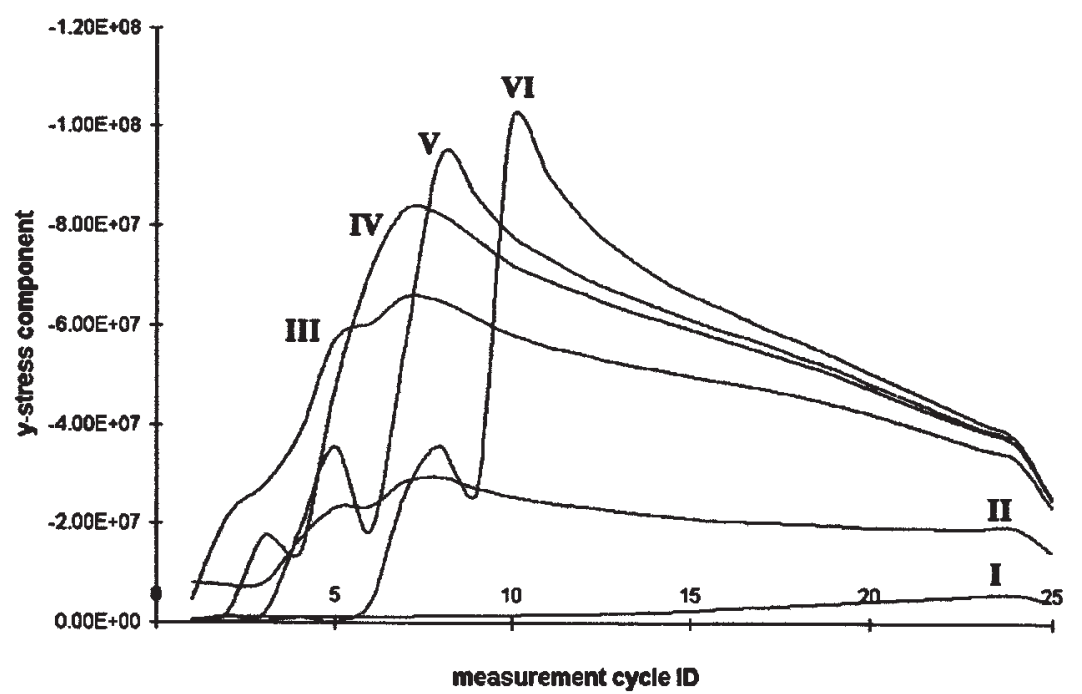

Fig. 7: Stress distribution along the coal mine (left side) I - 5000 cycles, II - 7000 cycles, III - 9000 cycles, IV - 12000 cycles, V - 15000 cycles, VI - 26000 cycles

The calculation method is a time stepping, explicit scheme. Modelling with $P F C^{2 D}$ involves the execution of many thousands of time steps. At each step, Newton's second law $($ force $=$ mass $\times$ acceleration $)$ is integrated twice for each particle to provide updated velocities and new positions, given a set of contact forces acting on the particle. Based on these new particle positions, contact forces are derived from the relative displacements for pairs of particles: a linear or non-linear force/displacement law at contacts may be used.

Fig. 5 and Fig. 6 show details of the mathematical model after a bump with ball velocities, and Fig. 7 shows the typical stress distribution along the coal mine. The stress grows (I, II) until the first bump initiation (III). This occurs at the $5^{\text {th }}$ measurement cycle approximately, then the stress decreases in this location, but it is increasing simultaneously at the $7^{\text {th }}$ measurement cycle, where the second bump initiation occurs (IV). The subsequent bump initiations can be expected in the $8^{\text {th }}$ and $10^{\text {th }}$ measurement cycles $(\mathrm{V}, \mathrm{VI})$.

\section{Conclusion}

A combination of experimental and mathematical models appears very appropriate for a study of the stress distribution in a coal seam before and after bump initiation. Both methods enable a time dependent study of the problem, and make it possible to study the development of cracks during bump initiation, and thes extrusion of material into an open space during a bump. They thus offer a description of the problem that is very close to reality.

\section{Acknowledgements}

This research and this article have been sponsored by the Grant Agency of Czech Republic, (GAČR), grant number 103/00/0530 "Experimental and mathematical study of coal seam loading before and after a bump" ("Experimentální a teoretická studie zatížení uhelné sloje před a po otřesu”). 


\section{References}

[1] Foss, M. M., Westman, E. C.: Seismic Method for in-seam coal mine ground control problems. SEG International Exposition and $64^{\text {th }}$ Annual Meeting, Los Angeles, 1994, pp. $547-549$

[2] Goodman, R. E.: Introduction to Rock Mechanics. John Wiley \& sons, 1989, p. 562

[3] Torańo, J., Rodríguez, R., Cuesta, A.: Using experimental measurements in elaboration and calibration of numerical models in geomechanics. Computation Methods and Experimental Measurements X, Alicante, 2001, pp. $457-476$

[4] Vacek, J., Procházka, P.: Rock bumps occurence during mining. Computation Methods and Experimental Measurements X, Alicante, 2001, pp. 437-446

[5] Vacek, J., Bouška, P.: Stress distribution in coal seam before and after bump initiation. Geotechnika 2000, Glivice-Ustroň 2000, pp. 55-66
[6] Vacek, J., Procházka, P.: Behaviour of brittle rock in extreme depth. $25^{\text {th }}$ Conference on Our World in Concrete \& Structures, Singapore, 2000, pp. 653-660

[7] Williams, E. M., Westman, E. C.: Stability and Stress Evaluation in Mines Using In-Seam Seismic Methods. $13^{\text {th }}$ Conference on ground control in mining, US Bureau of Mines, 1994, pp. 290-297

[8] Wood, D. M.: Soil Behaviour and Critical State Soil Mechanics. Cambridge University Press, 1996, p. 462

Doc. Ing. Jaroslav Vacek, DrSc.

phone: +420224353549

fax: +420224353855

e-mail:Vacek@klok.cvut.cz

Czech Technical University in Prague

Klokner Institute

Šolínova 7, 16608 Praha 6, Czech Republic 